\title{
特集＼cjkstart不動産流通市場の活性化 【論説】
}

\section{中古住宅流通の活性化をめぐる法的課題}

Legal Reform for the Promotion of Housing Market

Hiroshi MATSUO : Keio University

松尾弘*

In order to facilitate the market transaction of houses, a series of institutional reform seems relevant, such as: the unified system of disclosure of property information based on the standard format; the clarification of rights and duties of intermediary agent, and its empowerment through continuing education for consultation and provision of a built-in and one-stop services ; the development of a reasonable and fair appraisal method taking into consideration of renovation records; the provision of remedies for the defects of houses sold at public auctions. These reforms may become more efficient if they are combined with those reforms of the renovation market, the finance and taxation for the transaction of houses, and the securitization of rental houses.

keywords : house, promotion of housing market, disclosure of property information, intermediary agent, housing renovation 中古住宅，住宅流通の活性化，物件情報の開示，仲介業者，リフォーム

\section{1.はじめに一 一古住宅流通の活性化の 政策的意義と法的課題}

中古住宅流通の活性化は, 今日の日本において きわめて重要な政策的意義をもっている。それは, (1)人口減少と少子高齢化の中で, 新たな不動産市 場のフロンティアを開拓し, 関連産業を発展させ, 経済の活性化に寄与しうる。また, (2)それは流通 を契機にして, 耐震性を含む住宅の質を向上させ, ニーズに応じた住み替えを容易にし，国民の住生 活の充実を促して豊かさの実感を身近なものにし うる。さらに, (3)同じく流通を契機に, 省エネ性 を強化して環境負荷を低減し, 空家や危険建物の 放置問題への対応を促し, 循環型社会の実現によ る持続可能な発展への鍵を握るものとしても, そ
れは喫緊の政策課題といえる1。

しかし，はたして中古住宅市場は透明性の高い， フェアーで効率的な取引市場となっているであろ うか。むしろ, 現実には不透明な部分がなお多い のではなかろうか。このことは, 日本の住宅流通 は新築住宅が大半を占め, 中古住宅が少ないとい う事実にも示唆されている。この現象は, 住宅流 通の多くを中古住宅が占め, 新築住宅は一部にと どまる欧米と比べても，特徵的な現象といえる 2 それは一面では中古住宅の価值が評価されない結 果ともいえるし，他面では流通しないゆえに中古 住宅の価值が評価されずに低迷するともいえる鶏 卵的な難問である。いずれにしても，低品質の建 物, 低い評価, スクラップ・アンド・ビルドの建 築文化の存続, メンテナンスの不足, 中古住宅の

松尾弘* (まつお ひろし) 慶應義塾大学大学院法務研究科教授

1 不動産流通市場活性化フォーラム『提言』（2012年 6 月） 2 頁参照。 
流通阻害, ‥といった悪循環に陥っている。

では, 住宅の流通阻害と低品質との悪循環を断 ち切り, 中古住宅流通の活性化に向けた好循環へ のインセンティブを付与するために, どのような 制度改革の余地があるか。本稿はそのための法改 革の課題と対応の指針について検討する。

\section{2. 中古住宅市場改革の法的課題}

\section{（1）不動産物件情報システムの制度化}

（i）物件情報の開示内容の統一化・標準化 市場は，(1)誰が何をどれだけ必要としているか という情報を発見して伝達し, 資源を効率的に分 配する, (2)参加者が求める物やサービスを調達す る，(3)取引を通じて自由を享受する，(4)競争プロ セスを通じて技術革新を誘発する等の機能をも つ3。しかし, 日本の中古住宅市場は, (1)情報の発 見・伝達という市場の最も基礎的な機能からして 問題点を抱えている。その結果, 資源の効率的分 配, 購入者の満足, 自由の享受, 技術革新の誘因 といったいずれの機能に関しても, 未成熟な部分 を残している。

中古住宅市場が事業者・消費者がともに安心し て依拠できる透明性の高い物件情報を提供するた めには，まず，開示すべき情報内容の基準づくり から着手する必要がある。理念的には, (1)住宅の 性能（耐震性の診断結果, 床面積 $1 \mathrm{~m}^{2}$ 当たりのエ ネルギー消費量に換算した住宅の燃費等のランニ ング・コストを含む), (2)住宅の取引履歴 (成約価 格等, 過去の契約に関する情報を含む), (3)住宅の
地盤の履歴（土壤污染状況調査等を含む）, (4)修 繕・耐震改修等のリフォームの経過, (5)都市計画 法, 建築基準法等による規制, 課税やその控除, その他の法令に関する情報, (6)周辺地域の情報 (学区情報, マーケット情報等) の各内容につき, 売主や仲介業者が開示すべき情報項目を統一化し， 標準化することが望まれる4。そのためには, 成約 情報等の情報源となる売買契約書等の書式の標準 化も検討に值する。

これらの情報については, 徹底しでンプシに するう்が潜在的な買主の関心と安心感を高め, 結果的には売主や仲介業者にとってもメリットが 大きいことについて, 認識が共有されることがき わめて重要である。そのための事業者・消費者双 方の啓発が必要になるであろう。

\section{(ii) 物件情報の開示・管理方法}

つぎに，物件情報の開示を売主および宅建業者 （仲介物件の場合）に義務づけ, また, 開示による 売主の瑕疪担保責任の免責, その範囲での仲介業 者の説明義務違反の免責等, 売主側に何らかのイ ンセンティブを与える方法が必要になろう 5 。

その際, 仲介物件に関しては, 拡充された物件 情報の内容の統一化・画一化のためには, 重要事 項説明 (宅地建物取引業法35条 1 項)の内容の改訂 が要請されるであろう。と同時に，それを機会に， 重要事項説明の内容を精查し, 説明方法の効率化 も検討し, 消費者の能力とニーズにより適合した 物件情報の提供システムの改善を検討すべきであ る。

\footnotetext{
2 例えば, 日本では住宅流通量の 9 割近くを新築住宅が占め $(2008$ 年で約 109.3 万戸 $=86.5 \%)$, 中古住宅の流通シェアは濑 増しつつも 1 割強（2008年で約17.1万戸 $=13.5 \%$ ）にとどまっている（総務省：住宅・土地統計調查, 国土交通省 : 住宅 着工統計)。これに対し,アメリカに扔ける新築住宅の販売実績は, 1960年代以降年間平均約60万戸で推移している (1995 年から2005年にかけて増大して100万戸を突破したが, その後急隇し, 2008年以降は60万戸を下回る)。これに対し, 中古 住宅の販売実績は, 1969年の約160万個から著増して2006年には700万戸に達し, その後急落したが, 最低の2008年でも 400万件を超えている（http://www.ensus.gov/construction/nrs, http://www.realtor.org/research/research/ehsdata)。 とくに1990年代以降の中古住宅販売の伸びと不動産流通関連の制度改革との関係が注目される。小林正典「米国不動産流 通システムに学ぶ(1)」住宅新報2012年 5 月 22 日 2 面参照。

3 松尾 弘『良い統治と法の支配』(日本評論社, 2009) 148頁。

4 その内容は一戸建てとマンション（共用部分を含む）で様式が異なることも考えられる。

5 あるいは売却による所得に対するリフォーム代金の経費化等の措置も考えられる。

ちなみに, アメリカでは州政府が売主の告知書の様式を定め, その他の標準統一様式は (Multiple Listing Service:MLS) が決め，全不動産事業者に使用を義務づけている。
} 
なお，そのように拡充された開示すべき情報を もっぱら売主が保管することには限界があるかも 知れない。とくに相続等が生じた場合, 関連情報 が散逸することも考えられる。それは売主の自己 責任という面もあるが, 関連情報（前述(i)(1)（6) のすべてではないにしても, 一部は売主以外の者 (登記所等の公的機関, 過去に当該物件を取り引き した仲介業者等) がデータベース化してバック アップをすることも有益であろう。また，そうし た中古住宅の物件情報を管理する民間組織の設立 も検討に值する ${ }^{6}$ 。

その場合，これらの情報の正確性を公的に保証 する必要はないであろう。情報のソースをオープ ンにすれば, 必要に応じて利用者が独自に追加調 查することが可能であり, それが効率的だからで ある。

なお, 物件情報の開示・管理に関する現行の制 度として指定流通機構がある（Real Estate Information Network Systems for IP Services : REINS) ${ }^{7}$ 。それは共同仲介を制度理念とするが, 義務的登録項目が限られ, 物件の囲い込みが起こ りうる等の問題がある。物件情報の登載ルール(一 定時間内の掲載, ポケット・リスティングの禁止, 誇大広告の禁止と罰則等) 等, レインズ・ルール 自体の改訂, ルール遵守の徹底（インセンティブ 付与を含む) 等の制度改革の余地がある。

不動産物件情報の開示に関しては, 不動産登記 法に基づく登記制度の活用も考えられる。もっと
も，日本の不動産登記法は売買等の契約書そのも のを綴じる方式にはなっておらず, 売買価格等の 成約情報を開示するものではない8。また, 都市計 画法等の規制, 地歴等の情報を不動産登記簿に登 載する方式にもなっていない。しかし, 不動産物 件情報の統一化に向けて省庁間の連携による制度 改革の余地は大いにあるというべきである。

\section{（2）仲介業者の法的地位と権利・義務の明確化 \\ (i) 媒介契約の定義}

中古住宅市場の重要な担い手は, 媒介者（仲介 業者）としての宅地建物取引業者である。しかし， 宅建業者が顧客と締結する媒介契約については一 般法である民法に規定がない。現在進行中の民法 (債権法) 改正の議論では, 役務提供契約に関する 見直しの一環として, 媒介契約の定義が提案され

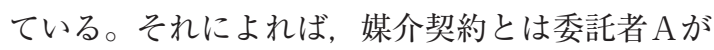
媒介者 Bに対し，A と第三者 C との法律行為が成

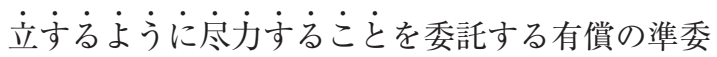
任である。そして，Bは委託の目的に適合するよ うに情報を収集し，Aに提供する義務を負う一方， その媒介によって A と C との間に法律行為が成立 したときは, BはAに報酬支払請求ができる ${ }^{9}$ 。し たがって,この要件を満たせば，AとCが自己取 引をしたときも， B は Aに報酬支払請求ができる。 媒介契約の定義化は, 仲介業者の法的地位とその 権利・義務を明確化する基盤になりうる。

\footnotetext{
6 一般社団法人・日本住宅建設産業協会は顧客が住宅を建設・販売した会社が同協会に所属する場合, その図面や保証書等 のバックアップ・サービスを提供している。アメリカの売却物件情報管理運営会社であるMultiple Listing Serviceに関し， 小林正典「米国不動産流通システムに学ぶ(2), (3)」住宅新報2012年 5 月 29 日 2 面, 6 月 5 日 2 面参照。

7 2007年 4 月からは, レインズが保有する不動産取引価格情報を活用した消費者向けの情報提供サービス (不動産取引情報 提供サイト：RMIによる）も始まっている。

8 売買等の不動産物権変動の原因証書は, 添付情報として登記申請に際して添付されるにとどまる。

9 民法（債権法）改正検討委員会『債権法改正の基本方針』(商事法務，2009。以下，委員会方針という)【3.2.10.19】。法制 審議会民法（債権関係）部会『民法(債権関係)の改正に関する中間的な論点整理』(平成23年 4 月12日決定。以下，中間 整理という）49.6(1)参照。現行法は商事仲立に関する規定のみを設けている（商法543）。

ちなみに，現行民法は，委任は法律行為の委託（民法643），準委任は法律行為でない事務の委託（民法656）とするが， この提案は委任の定義を維持しつつ, 準委任は委任者が受任者に「第三者との間で」法律行為でない事務を行うことを委 託する場合に限定する趣旨である。この提案によれば，当事者間 $\mathrm{AB}$ 間での役務提供のように「第三者との間」で行われ るのでない事務処理の委託は，準委任ではなく，役務提供契約の対象になる。委員会方針【3.2.10.01】，【3.2.10.02】。中間 整理49.5。
} 
(ii） 仲介業者のコンサルティング機能の向上と研 修制度の充実

媒介契約の受任者としての法的地位を基盤にし つつ, 宅建業者はそのコンサルティング機能を向 上させ, 顧客 (委任者) の希望（中古・新築の売買, リフォーム, 賃貸, その他の不動産活用等）に即 してワンストップ・サービス（例えば, 中古住宅 の紹介と同時にリフォーム提案, 瑕疪担保保険の 紹介をする等) を可能にすることが期待される ${ }^{10}$ 。 ここではアメリカにみられるような不動産流通関 連事業者の分業化, それらの間の連携強化による 不動産流通のネットワーク化, 不動産エージェン トを空口とするサービスのパッケージ化が参考に なる11。それは地域経済の活性化に寄与するであ ろう。もっとも, それによる不動産取引にかかる コストの増大が, サービスの向上に見合ったもの であるかをつねに検証する必要がある。

仲介業者によるコンサルティング機能の向上は, 不動産仲介業者および宅地建物取引主任者に対す る継続教育・研修制度の充実・強化と不可分であ る。その際, 研修の義務づけや研修の受講に対す る評価制度等，研修を受けることのインセンティ ブを付与する仕組みに配慮する必要がある ${ }^{12}$ 。

\section{（3）住宅の価格査定方法の制度化}

中古住宅の流通促進のためには建物の資産価值 の適正な評価方法の確立が不可欠である。その際 にはリフォーム結果を価格に的確に反映させる仕 組みが必要になる。そのためには物件情報（前述 (1)(i)）を蓄積し，容易に利用可能な形にデータ ベース化するシステム, 建物価格査定基準の合理 化と統一化, 建物検査（ホーム・インスペクショ ン）の制度化（不動産取引のどの夕イミングで, 誰の費用負担で行うかも含む) 等が必要になる ${ }^{13}$ 。

\section{（4）競売・公売物件の流通促進のための法改革}

中古不動産の取引は競売や公売（租税滞納処分 等）を通じても行われる。強制競売された物件に 権利の瑕疵があった場合, 買受人は, (1)債務者 (前所有者)に対して代金減額請求または契約解除 ができるが，(2)債務者が無資力であるときは代金 の配当を受けた債権者に対して代金の全部または 一部の返還を請求でき, (3)悪意の債務者・債権者 に対しては損害賠償を請求できる(民法568)。し かし, 物の瑕疪に関しては, 買受人は債務者（前 所有者)にも配当を受けた債権者にも損害賠償(代 金減額) 請求等の担保責任を追及できない(民法 570)。これは担保権の実行としての競売および公 売の場合も妥当する。その理由は, (1)これらの場 合は前所有者の自発的意思によって売却されたも のでないこと, (2)債権者は物の性状について知る 機会が少ないこと, (3)買受人は自己の危険で買い 取るべきこと等による14。

しかし, それは債権者保護に偏り, 競売・公売 市場を意識したルールとはいい難い。前所有者も 債権者も強制競売等の可能性は当初から認識可能 であり, 競売・公売市場に参加する買主の信頼を 確保するためにも, 物の瑕疪に対する債務者（前

10 それに向けた取組みはすでに業界でも始まっている。「不動産仲介事業を刷新」日本経済新聞2012年 7 月15日号(地方経済 面・神奈川26頁)。

11 アメリカでは, 不動産取引に関わる専門家として, 不動産エージェント（日本の宅建業者に当たる）が顧客に対してコン サルティング・サービスを提供しつつ, 不動産ブローカー(不動産会社), エスクロー(条件調整, 書類確認, 精算), アプ

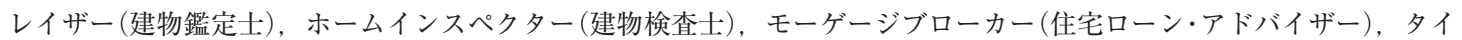
トル会社 (権原調查保証会社) の間のネットワークが形成されている。小林正典「米国不動産流通システムに学ぶ(2)」住 宅新報2012年 5 月29日号 2 面。

12 全国宅地建物取引業協会連合会＝全国宅地建物取引業保証協会『教育研修制度のあり方に関する調査研究事業』(2012年), 小林正典「米国不動産流通システムに学ぶ(4)」住宅新報平成12年 6 月 12 日参照。

13 不動産流通市場活性化フォーラム（以下，フォーラムという)『提言』(2012年 6 月） 3 頁。アメリカに扔ける住宅価格の 適正な評価システムに関し，小林正典「米国不動産流通システムに学ぶ(5)」住宅新報2012年 6 月 19 日号 2 面参照。

14 『新版・注釈民法(14)』(有斐閣，1993）371頁（柚木馨＝高木多喜男）。 
所有者）および債権者の責任を導入する方向で法 改正を検討すべきである ${ }^{15}$ 。

\section{3.リフォーム市場の改革}

中古不動産の流通促進はリフォーム市場の改革 とも密接に結びついている。中古物件の潜在的な 買主にとっては, リフォームに関する事業者・費 用・品質等に関する情報が不足しており, 消費者 の不安が解消されていないという問題がある。対 応策の一つとして, 優良リフォーム業者の格付け 制度の導入が検討されている16。また, リフォー ムが中古住宅の資産・担保価值を高めることに確 信がもてるような制度改革が必要である。そのた めには, リフォームの客観的な評価制度を建物の 価格査定制度の改善（前述 $2(3)$ ) と連動させる必 要がある。さらに,リフォーム工事に瑕疪があっ た場合に備え, リフォーム瑕疪保険, 大規模修繥 瑕疪保険の普及促進に加え, 注文者の修補 - 損害 賠償請求, 契約解除, 解除の場合における請負人 の原状回復等に関し，民法改正の余地がある ${ }^{17}$ 。

\section{4. 住宅金融，税制等に関する制度改革}

中古住宅流通市場の拡大・縮小の決定要因とし て, 国民の実需に加え, 長期で安定した低利融資, 譲渡税の控除, 住宅ローン利子控除等の制度も無 視できない。しかし, 日本では, 新築住宅購入に 比べ, 中古住宅購入の場合, たんなる築年数の経 過が建物評価を大きく左右し, 住宅ローンおよび 住宅ローン控除の利用を妨げている ${ }^{18}$ 。こうした 現行の住宅価格評価制度の改革（前述 $2(3))$ は急 務である。

また, 住宅金融を促進するためには, 借主の債
務不履行が生じた場合の対応制度を充実させるこ とも重要である ${ }^{19}$ 。

さらに, 高齢者の住み替え, 安定居住を促進・ 確保するために, 売却しなくても住み替えが容易 にできるよう, リバースモーゲージ等の普及のた めの制度改革を探る余地もある。

また，税制との関係では，買取り再販を促進す るための不動産取得税の減免 (二重課税の回避), 譲渡損失の損益通算に関する要件の緩和等も検討 の余地がある。

\section{5. 賃貸不動産の流通促進}

中古住宅はそれが貨貸物件であることもある。 その場合, 賃借人に貸したままでも円滑に物件を 売買することができるよう, 賃貸物件の流動化も 中古住宅の流通の促進には不可欠である。現在の 判例は, 賃貸不動産が譲渡された場合は,「特段の 事情」がないかぎり, 賃貸人の地位は譲受人に当 然承継されると解している。そして, (1)賃借人の 同意がないかぎり, 譲渡人と譲受人の間で賃貸人 の地位を譲渡人に留保する旨の合意をしても「特 段の事情」とは認められないとしている20。しかし, 譲受人は物件の賃貸管理をする意思も能力もない 場合もあり, 賃貸不動産の流通促進のためには判 例の基準を緩和する余地がある。また, (2)賃貸物 件の譲渡に伴って賃貸人の地位もいったん承継し た譲受人が，賃貸管理を専門業者たる第三者に委 ねるために，賃貸人の地位のみを当該第三者に移 転することを望む場合もある。これら(1)・(2)の場 合に賃借人の同意がなくとも, 賃貸物件の所有権 と賃貸人の地位の分離を認めても賃借人の利益保 護に反しない要件を検討する余地がある ${ }^{21}$ 。

\footnotetext{
15 松尾弘『民法改正を読む』(慶應義塾大学出版会, 2012) 148-149頁参照。委員会方針【3.2.1.20】はその方向性を示す。中 間整理39.4参照。柚木＝高木・前掲（注14）372頁は民法568条 3 項を物の瑕疵にも類推適用すべきとする。

16 フォーラム・前掲 (注13) 7 頁。

17 松尾・前掲（注15） 167-168頁参照。

18 住宅ローン減税・贈与税の特例における建築年数要件（木造20年, マンション25年）等が制度的障害になっている。

19 不動産の買取ファンド・買取機構の創設も検討されている。フォーラム・前掲（注13） 9 頁。

20 最判平成11年 3 月 25 日判例時報1674号61頁。

21 松尾弘「不動産流動化の要請と賃貸人の地位」NBL 982号（2012）58-67頁参照。
} 
6. おわりにー国際化・グローバル化の波 と不動産流通革命?

以上に概観した諸点の法改革は相互に連動して おり, ワン・パッケージの制度改革として取り組 む必要がある。それを通じ, 売主・買主・仲介業 者・融資者・リフォーム業者・その他の関係者が いずれも納得のゆくような, 合理的で効率的な取
引ができるように促すことが急務である。それが 未開拓の中古住宅流通市場を活性化し, 日本でも 「不動産流通革命」が起こるかどうかは分からない。 しかし, 中古住宅市場にも国際化およびグローバ ル化の波が押し寄せていることに鑑み 22 , それに 備えて国内ルールを合理的で効率的なものに整え ておくことは不可避といえよう。

22 2012年秋には, 全米リアルター協会（NRA）が日本オフイスを開設する模様である。小林正典「米国不動産流通システ 厶に学ぶ(3)」住宅新報2012年 6 月 5 日 2 面。 